Avoimesti luettavissa osoitteessa http://journal.fi/ainedidaktiikka

\title{
Foneettinen osaaminen helpottaa vieraan kielen ääntämisen opettamista - kyselytutkimus suomalaisten kieltenopettajien käyttämistä ääntämisen opetusmenetelmistä.
}

\author{
Päivi Virkkunen ja Minnaleena Toivola
}

Humanistinen tiedekunta, Helsingin yliopisto

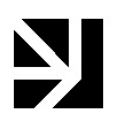

Tässä tutkimuksessa selvitettiin suomalaisten kieltenopettajien ääntämisen opetuksen käytänteitä. Halusimme selvittää erityisesti foneettisen koulutuksen riittävyyttä ja sen vaikutusta opettajien kokemukseen ääntämisen opetuksesta. Kyselytutkimuksen vastaajat $(n=175)$ arvioivat oman ääntämistaitonsa pääosin hyväksi, mutta he olivat silti epävarmoja ääntämisen opettamisesta. Merkittävänä tuloksena voidaan pitää opettajien oman koulutuksen sisältöjen tärkeyttä: mitä enemmän koulutuksessa on ollut fonetiikan opetusta, sitä helpompana vastaajat pitävät ääntämisen opettamista. Opettajat, jotka pitävät ääntämisen opetusta helppona, opettavat myös enemmän prosodiaa, joka on puheen ymmärrettävyydelle tärkeä suullisen kielitaidon osa-alue. Tuloksia voidaan hyödyntää opettajankoulutuksen ja opettajien täydennyskoulutuksen kehittämisessä. Opettajien kautta voidaan vaikuttaa opetuksen sisältö̈ihin ja auttaa oppijoita saavuttamaan parempi ääntämistaito.

Eksplisiittinen opetus, fonetiikka, opettajankoulutus, vieraan kielen opetus, ääntäminen

Lähetetty: 2.10.2019

Hyväksytty: 15.3.2020

Vastuukirjoittaja: paivi.virkkunen@helsinki.fi

DOI: $10.23988 / \mathrm{ad} .85736$ 


\section{Johdanto}

Kielitaidon merkitys kasvaa jatkuvasti, kun eri kieli- ja kulttuuritaustoista tulevat ihmiset elävät, toimivat ja työskentelevät yhdessä kansainvälistyvässä maailmassa. Ääntäminen on tärkeä kielitaidon osa-alue, sillä suuri osa ihmisten välisestä kommunikaatiosta tapahtuu puhumalla. Kielenopetus on murrosvaiheessa Suomessa ja kansainvälisesti, kun kommunikatiivista lähestymistapaa korostavien opetusmallien jälkeen ääntämiseen ollaan jälleen kiinnittämässä enemmän huomiota (esim. Murphy \& Baker, 2015). Nykyisissä perusopetuksen opetussuunnitelman perusteissa (Opetushallitus, 2016) korostetaan foneettisia taitoja ja kykyä toimia vuorovaikutuksessa vieraalla kielellä, ja ylioppilastutkintolautakunta suunnittelee suullisten kielikokeiden lisäämistä ylioppilastutkintoon lähivuosina (Ylioppilastutkintolautakunta, 2017).

Tella ja Harjanne (2004) nostavat kielididaktiikan tärkeimmiksi alueiksi vieraan kielen opetuksen ja opiskelun. Ääntämisen opetuksen näkökulmasta kielididaktisessa prosessissa korostuvat opetuksen sisällöt ja menetelmät. On kuitenkin tiedossa, että vaikka puhuminen ja kirjallinen ilmaisu ovat opetustavoitteina periaatteessa tasaveroiset, jää puhuminen helposti sivuosaan pitkälti ylioppilaskokeista toistaiseksi puuttuvan, suullista kielitaitoa mittaavan osion takia (Hilden, 2020). Suomessa ääntämisen opettamista on aiemmin tutkittu vain englannin kielen osalta (Tergujeff, 2013), eikä kielididaktiikkaa ole foneettisesta näkökulmasta tutkittu käytännössä lainkaan.

Pelkkä pedagoginen osaaminen ei riitä, kun suunnitellaan toimivaa ja tehokasta vieraan kielen ääntämisen opetusta. Hyvältä ääntämisen opettajalta vaaditaan sekä pedagogista tietoa opettamisesta että foneettista tietoa artikulaatiosta, äänteistä ja puheen prosodisista ominaisuuksista (Murphy, 2017). Fonetiikka on tieteenala, joka tutkii puhetta, sen tuottamista ja havaitsemista kieliriippumattomasti. Kaikki puhe tuotetaan samankaltaisten anatomisten rakenteiden avulla, mutta maailman kielet eroavat toisistaan sen suhteen, millaisia äänteitä niihin kuuluu ja miten niitä yhdistellään puheeksi. Ymmärrys puheen foneettisesta perustasta, kuten äänteiden muodostuksesta sekä puheen havaitsemisesta, tukee ääntämisen oppimista sen kaikilla tasoilla.

Kieltenopettajien oma koulutus ja asenteet ääntämisen opettamista kohtaan ovat kasvavan kiinnostuksen kohteena useilla kielialueilla (ks. esim. Burri, Baker \& Chen, 2018; Huensch, 2019; Uchida \& Sugimoto, 2020). Pidämme tärkeänä myös suomalaista tutkimusta tästä aihealueesta. Tutkimuksessamme selvitämme kieltenopettajien käsityksiä ääntämisen ja fonetiikan tärkeydestä osana kielenopetusta sekä opettajien nykyisin käyttämiä ääntämisen opetusmenetelmiä. Haluamme selvittää erityisesti foneettisen koulutuksen riittävyyttä ja sen vaikutusta ääntämisen opetuksen koettuun helppouteen. Tarkastelun kohteena ovat erityisesti opettajat ja opetusmenetelmät, mikä korostaa tutkimuksen didaktista luonnetta. Ainedidaktiikka ymmärretään laajana ja monitieteisenä tutkimuskohteena 
(Tella \& Harjanne, 2004) ja tämä tutkimus yhdistää ääntämisen oppimiselle välttämättömät osatekijät: didaktiikan, kielen ja fonetiikan.

\section{Vieraan kielen ääntämisen oppiminen}

Vieraan kielen oppimisen tavoitteena ei yleensä ole natiivinkaltainen kielitaito, vaan kommunikatiivinen kompetenssi eli taito kommunikoida kielellä ja käyttää sitä tarkoituksenmukaisesti erilaisissa tilanteissa (Derwing \& Munro, 2009; Pietilä \& Lintunen, 2014). Kielitaito koostuu monesta osa-alueesta, joita ovat muun muassa puheen ja tekstin tuottaminen, kuullun ymmärtäminen sekä sanaston, kieliopin ja rakenteiden hallinta. Kielitaidon osa-alueet nivoutuvat tiiviisti yhteen, eikä esimerkiksi kuullunymmärtämistä ja puheentuottoa voida täysin erottaa toisistaan (Flege, 1995; Sakai \& Moorman, 2018). Opettajan haasteena on tuoda kaikki kielitaidon osa-alueet kattavasti esille oppitunneilla, jotta oppija voi saavuttaa monipuolisen kielitaidon.

Puhe on ihmisen ensisijainen kommunikaatiomuoto, ja ensimmäinen arvio keskustelukumppanin kielitaidosta tehdään usein ääntämisen perustella (Lintunen, 2014). Ääntäminen on siten tärkeä osa kielitaitoa ja se tulisi huomioida opetuksessa tasapuolisesti muiden kielitaidon osaalueiden kanssa. Ääntämistaito koostuu kahdesta pääoppimiskohteesta: segmentaalisesta ja prosodisesta tasosta. Segmentaalinen taso sisältää äänteet, jotka ovat puheen pienimmät merkitystä erottavat segmentit. Prosodinen taso koostuu äännesegmenttejä laajemmista kokonaisuuksista, kuten intonaatiosta, sana- ja lausepainosta tai puherytmistä ja -nopeudesta.

Puhe on monimutkaista motorista toimintaa, mutta emme yleensä joudu sitä pohtimaan, sillä puhumme äidinkieltämme niin sujuvasti kaikkine virheineenkin. Ymmärrämme usein puheentuoton motorisen vaativuuden vasta opiskellessamme vierasta kieltä, kun äidinkielestä poikkeavien äänteiden tuottaminen edellyttää ääntöelimistön uudenlaista käyttöä. Toisaalta pelkkä motoristen liikeratojen toistaminen ei välttämättä riitä, jos meillä ei ole käsitystä siitä, mitä olemme tekemässä. Ääntämisen oppimista voidaankin edistää lisäämällä opetukseen tietoa puheentuotosta, äänteistä ja kohdekielen äännejärjestelmästä (ks. esim. metatutkimukset Lee, Jang \& Plonsky, 2015; Saito, 2012; Thomson \& Derwing, 2015). Tämä on erityisen tärkeää silloin, kun kontaktit kohdekielen puhujiin ovat vähäisiä (Dörnyei, 2009), kuten suomalaisen koulussa tapahtuvan kielenopetuksen tapauksessa usein on. Vaikka kohdekielisessä ympäristössä opiskelu, esimerkiksi opiskelijavaihdon tai kielikurssien aikana, yleensä parantaa suullisen kielitaidon sujuvuutta (Ullakonoja, 2011) ja käyttövalmiutta, se ei kuitenkaan automaattisesti paranna äännetason puheentuottoa (Segalowitz ym., 2004). Äännetietoisuutta voidaan lisätä esimerkiksi käyttämällä opetuksessa foneettisia merkkejä (International Phonetic Alphabet, 2018, jatkossa IPA). IPAn etuna on se, että yhtä äännettä vastaa aina yksi merkki, jolloin IPAlla kirjoitetun tekstin lukeminen on lähes yhtä helppoa kuin esimerkiksi suomen, jonka kirjain-äänne-vastaavuus on suuri (Lintunen, 2014).

Iän vaikutusta ääntämisen oppimiseen on tutkittu runsaasti. Kriittisen periodin hypoteesi (Lenneberg, 1967) esittää, että kielen oppiminen vaikeutuu noin 9-12-vuotiaana, kun aivojen plastisuus vähenee neurologi- 
sen kypsymisen myötä. Tämän ajatellaan johtavan siihen, että kielenoppijan on mahdotonta saavuttaa natiivinkaltainen ääntämistaito murrosiän jälkeen, ja hänen puheeseensa jää aina jonkinlainen vieras aksentti. Lukuisissa eri tutkimuksissa (ks. kooste Derwing \& Munro, 2015) onkin havaittu yhteys kielenoppimisen aloitusiän ja havaitun vieraan aksentin vahvuuden välillä siten, että mitä nuorempana kielenoppiminen on aloitettu, sitä natiivinkaltaisempaa ääntäminen on.

Kriittisen periodin tulkintaa haastavat tutkimukset, joissa esitellään vasta aikuisena kielenopiskelun aloittaneita, erittäin hyvän kielitaidon saavuttaneita puhujia (Bongaerts, Mennen \& Slik, 2000; Ioup, Boustagui, El Tigi \& Moselle, 1994; Muñoz \& Singleton, 2007). Ääntämistaidon kehittyminen natiivinkaltaiseksi (tai lähelle sitä) aikuisiällä vaatii kuitenkin suurta motivaatiota, intensiivistä harjoittelua ja kognitiivisen kielitietoisuuden lisäämistä (Bongaerts, 1999). Nykyisin puhutaan myös niin sanotusta sensitiivisestä vaiheesta (Lamendella, 1977), jota voidaan käyttää kriittisen periodin synonyymina (Marinova-Todd, Marshall \& Snow, 2000).

Kielenoppijan tavoitteena ei kuitenkaan yleensä ole täysin natiivinkaltainen puhe, vaan tärkeämpää on sujuva ja ymmärrettävä puheentuotto. Aikuinenkin kielenoppija pystyy oppimaan uuden kielen, mutta edelleen tutkijat ovat suhteellisen yksimielisiä siitä, että older is faster, but younger is better (vanhempana nopeammin, mutta nuorena paremmin), millä kuvataan oppimisen eroja eri-ikäisillä oppijoilla. Toisaalta DeKeyser (2019) muistuttaa, että lasten implisiittisen oppimiskyvyn edut eivät pääse täysin esille perinteisessä, muutaman viikkotunnin luokkahuoneopetuksessa, joten olisikin erityisen tärkeää kiinnittää huomiota siihen kieleen, jota lapset kuulevat tunneilla. Aikuisen ja lapsen kognitiiviset kyvyt ovat erilaiset, joten myös parhaat oppimiskeinot ovat erilaisia. Yleensä kuitenkin aikuiset oppivat kielen rakenteita nopeammin, kun taas lapset oppivat nopeammin ääntämään (Pietilä, 2014).

Couperin (2003) mukaan tärkeimpiä ääntämisen oppimiseen vaikuttavia seikkoja ovat oppijan motivaatio (ks. esim. Marinova-Todd, Marshall \& Todd, 2000; Yousofi \& Naderifarjad, 2015), motoristen taitojen harjoittelu (Kissling, 2013), teoriatieto äänteiden ja puheen tuottamisesta (Lord, 2005; Sturm, 2013) sekä analyyttinen, kognitiivista kielitietoisuutta lisäävä vieraan kielen kuuntelutaito (Thomsom, 2011; Yule, Hoffman \& Damico, 1987). Kannustava oppimisympäristö sallii aktiivisen harjoittelun lisäksi myös oppimisprosessiin kuuluvat oppimista edeltävät virheet (Wrember, 2001).

\section{Eksplisiittinen ääntämisen opetus}

Pieni lapsi omaksuu implisiittisesti (yhden tai useamman) äidinkielensä ääntämisen, kun hän on vuorovaikutuksessa huoltajansa kanssa ja kuulee kieltä puhuttavan ympärillään. Sama pätee myös vieraan kielen ääntämiseen, jos lapsi on tarpeeksi nuori altistuessaan vieraalle kielelle (DeKeyser, 2018). Teini-ikäisillä ja aikuisilla oppijoilla opettajan rooli ääntämisen oppimisessa on kuitenkin usein erittäin merkittävä, sillä itsenäinen ääntämisen kehittyminen vaatii jatkuvan harjoittelun lisäksi oppijan erityistä lahjakkuutta (Lintunen \& Dufva, 2019). Vaikka oppijat kuulevat jatkuvasti tunneilla vierasta kieltä opettajan puhumana tai muiden lähteiden kautta, 
ääntämistä tulee opettaa myös eksplisiittisesti, erityisesti siihen keskittyen. Eksplisiittinen opetus, joka lisää oppijan kognitiivisia taitoja ja tietoisuutta puheesta, sisältää esimerkiksi oman puheen monitorointia ja korjaamista, kuuntelu- ja puheentuottoharjoituksia sekä kohdekielen äännejärjestelmään tutustumista ja sen analysointia (Derwing, Munro \& Wiebe, 1998; Dörnyei, 2009; Lintunen, 2014). Tärkeää on kuitenkin integroida ääntämisen opetus kaikkeen kielenopetukseen, jotta se ei jää vain irralliseksi osioksi, vaan yhdistyy kielitaidon kokonaisuuteen (Jones, 1997).

Puheentuottoa voi olla vaikea konkretisoida, sillä artikulaatioelimistön liikkeet eivät juurikaan näy päälle päin. Ääntöväylän poikkileikkauskuvat ja esimerkiksi internetistä löytyvät fMRI-videot ${ }^{1}$ auttavat hahmottamaan fysiologisia rakenteita ja kielen liikkeitä äänteiden tuoton aikana. Kieltenopetukseen tulisikin lisätä vaihtelevia opetusmenetelmiä ja analyyttisia, kognitiivista kielitietoisuutta lisääviä oppimateriaaleja (Pietilä, 2014).

IPA on yksi tapa lisätä tietoisuutta opiskeltavasta kielestä ja sen piirteistä (Lintunen, 2004; Mompean \& Lintunen, 2015; Rajab, 2013). IPA-merkkejä käytetään yleensä eniten äänteiden kuvaamiseen, mutta niillä voidaan merkitä myös esimerkiksi sanapainoa, jolla saattaa olla sanan merkityksen muuttava vaikutus. IPAn edut tulevat esille erityisesti silloin, kun opiskellaan kieltä, jonka kirjain-äänne-vastaavuus on heikko (esimerkiksi englanti tai ranska), sillä sen avulla ääntämistä voidaan kuvata ilman ortografiaa. Kirjoitetun sanan näkeminen saattaa ohjata ääntämistä väärään suuntaan, erityisesti uuden sanaston opiskelun aikana (Bassetti, 2008; Hayes-Harb, Nicol \& Barker, 2010; Rafat, 2013). Ääntämisen oppimisen tulee lähteä kuullusta ja puhutusta kielestä eikä kirjoitetusta muodosta, mutta puhetta on mahdollista visualisoida IPAn avulla. Suomessa perusopetuksen opetussuunnitelman perusteissa (Opetushallitus, 2016) myös mainitaan foneettinen kirjoitus jo alakoulun A-oppimäärän sisällöissä: "Harjoitellaan tunnistamaan englannin kielen foneettisen tarkekirjoituksen merkkejä." Yläkoulussa mukaan tulee kaikkien vieraiden kielten oppimäärissä myös kirjoittaminen: "Harjoitellaan tunnistamaan opiskeltavan kielen foneettisen tarkekirjoituksen merkkejä sekä tuottamaan tarvittavia kirjoitusmerkkejä."

Tutkimuksissa on havaittu, että yleisen fonologisen tietoisuuden määrä korreloi ääntämisen ymmärrettävyyden kanssa (Venkatagiri \& Levis, 2007) ja erityisesti kohdekielen prosodian opettamisen on havaittu helpottavan vieraan kielen ymmärtämistä (Kissling, 2018). Lisäksi Lintunen (2004) on havainnut foneettisen kirjoituksen osaamisen ja ääntämisen välisen yhteyden. Hänen tutkimuksessaan suomalaiset englannin yliopisto-opiskelijat, jotka suullisen kielitaidon kurssin aikana oppivat parhaiten transkriboimaan tekstiä, kehittyivät myös eniten ääntämisessään ja kykenivät parhaiten korjaamaan puhettaan äännetasolla. Eksplisiittisen opetuksen hyödyt ääntämisen oppimiselle on havaittu myös muissa tutkimuksissa (esim. Couper, 2003; Peltola, Lintunen \& Tamminen, 2014;

\footnotetext{
${ }^{1}$ fMRI eli toiminnallinen magneettikuvaus (functional Magnetic Resonance Imaging) on lääketieteellinen kuvantamismenetelmä. Se on nykyisin yleisesti käytetty menetelmä puheentuoton tutkimuksessa (ks. esim. Lawson, Stuart-Smith, Scobbie \& Nakai, 2018; Palo ym., 2012).
} 
Saito, 2011). Lisäksi on havaittu, että vaikka sekä implisiittistä että eksplisiittistä opetusta saaneiden kiinankielisten englanninoppijoiden oppimistulokset olivat parantuneet heti opetusjakson jälkeen, vain eksplisiittistä opetusta saaneilla tulos oli pysyvä myös myöhemmissä testeissä (Chung 2008, viitattu Hamzah, 2014). Japaninkielisille englanninoppijoille vaikean $[1]-[\mathrm{I}]$-eron havaitseminen ja tuottaminen paranivat, kun opiskelijoille tarjottiin eksplisiittistä foneettista tietoa äänteistä ja niiden eroista. Lisäksi oppijat pystyivät yleistämään oppimansa äänne-eron käyttöön myös muissa kuin harjoitelluissa sanoissa (Saito, 2013).

Vaikka vieraan kielen ääntämisen vaikeudet johtuvat yleisemmin kognitiivisen kuin motorisen kielitaidon puutteesta (Fraser, 2000), niin esimerkiksi Kissling (2013) muistuttaa, että foneettinen teoriaopetus ei saa korvata runsasta motorista harjoittelua ja palautteenantoa, jotka ovat tärkeitä edellytyksiä ääntämisen kehittymiselle. Ilman palautetta oppija ei välttämättä ole tietoinen omasta ääntämisestään, siinä esiintyvistä virheistä ja sen kehittymisestä (Tergujeff, Heinonen, Ilola, Salo \& Kara, 2019).

\section{Aiempi tutkimus ääntämisen opetuksesta}

EPTiES (English Pronunciation Teaching in Europe Survey) -hanke selvitti vuosina 2010-2011 englanninopetusta 31 Euroopan maassa. Vastaajilla oli yhteinen ongelma ympäri Eurooppaa: opettajille oli tarjottu heidän omaan ääntämiseensä keskittynyttä koulutusta, mutta he eivät olleet saaneet tietoa siitä, miten ääntämistä opetetaan. Kyselyyn vastanneet suomalaisopettajat $(n=103)$ pitivät ääntämistä tärkeänä kielitaidon osana, mutta silti he opettivat sitä vähemmän kuin olisivat halunneet, mikä johtui oletettavasti osin osaamisen puutteesta (Tergujeff, 2012).

Kieltenopettajien koulutuksessa keskitytään opettajan omaan ääntämiseen ja sen kehittymiseen, mutta puutteellinen koulutus ääntämisen opettamisen käytänteistä voi johtaa epävarmuuteen opetustyössä, ja epävarma opettaja tukeutuu todennäköisemmin oppikirjoihin (Tergujeff, 2013). Suomalaisten oppikirjojen ääntämisharjoitukset keskittyvät äänteisiin ja yksittäisiin sanoihin, jolloin prosodian opetus jää tunneilla hyvin vähäiseksi (Heinonen, tulossa; Tergujeff, 2010; Tergujeff, 2019). Tutkimuksissa on kuitenkin havaittu, että juuri puheen prosodiaan keskittyvä ääntämisen opetus parantaa vieraskielisen puheen sujuvuutta (Derwing \& Munro, 2005; Derwing, Munro \& Wiebe 1998; Hahn, 2004). Suomalaisissa kouluissa ääntämistä on opittu lähinnä implisiittisesti muiden suullisten keskusteluharjoitusten yhteydessä. Fonetiikkaa tai IPAa ei ole hyödynnetty opetuksessa juuri lainkaan ja esimerkiksi artikulaation fysiologisen perustan selittäminen tai foneettisen terminologian käyttö on ollut harvinaista (Tergujeff, 2013).

Suomalaiset englannin yliopisto-opiskelijat suhtautuivat myönteisesti IPAn käyttöön eksplisiittisen kielenopetuksen osana (Mompean \& Lintunen, 2015). Lähes $90 \%$ vastaajista $(n=52)$ koki, että IPAn käyttö oli lisännyt heidän tietoisuuttaan niistä englannin äänteistä ja äänneyhdistelmistä, joita ei esiinny suomessa. Lisäksi noin 70 \% vastaajista oli käyttänyt IPAa opiskellessaan kieltä itsenäisesti ja kokenut saaneensa siitä apua oman ääntämisensä kehittymiseen.

Tuore tutkimus (Huensch, 2019) osoittaa, että yhdysvaltalaisilla vieraan kielen (ranska, saksa, espanja) opettajilla on samankaltaisia ongelmia 
kuin eurooppalaisilla kollegoillaan. Tutkimuksen kyselyyn vastanneista opettajista $(\mathrm{n}=296)$ vain $13 \%$ oli käynyt ääntämisen opettamisen kursseilla, ja $67 \%$ vastaajista toivoi lisää koulutusta ääntämisen opetuksesta. Lisäksi $30 \%$ vastaajista kertoi, että heidän käyttämissään oppikirjoissa ei ollut lainkaan ääntämisharjoituksia. Myös Uchidan ja Sugimoton (2020) tutkimuksessa japanilaiset englanninopettajat $(\mathrm{n}=100)$ kokivat, ettei heidän koulutuksensa ollut valmistanut heitä ääntämisen opettamiseen. Ne opettajat, jotka olivat viettäneet aikaa englanninkielisessä ympäristössä (esim. opiskelijavaihdossa) olivatkin varmempia omasta ääntämisestään ja he myös pitivät ääntämisen opettamista muita opettajia tärkeämpänä.

Aiemmin mainittujen Suomessa ja ulkomailla tehtyjen tutkimusten mukaan kieltenopettajilla ei ole riittävästi tietoa ääntämisen opettamisesta. Opetus jää usein implisiittiselle tasolle, sillä opettajat kokevat tarvitsevansa lisää oppimateriaaleja sekä tietoa ääntämisen opetuksesta voidakseen tarjota eksplisiittistä opetusta. Tutkimusten tuottamat suositukset ääntämisen opettamisesta ja opetuksen todelliset käytänteet ovat usein aika kaukana toisistaan, mikä voi johtua siitä, että tutkimustieto ei saavuta kielenopettajia helposti (Foote, Trofimovich, Collins \& Urzúa, 2016). Tergujeffin (2014) mukaan opettajankoulutuksen tulisikin olla ensisijaisena kehityskohteena, kun halutaan auttaa oppijoita saavuttamaan parempi ääntämistaito.

\section{Tutkimustehtävä}

Tässä tutkimuksessa tarkastelun kohteena ovat suomalaisissa kouluissa työskentelevien kieltenopettajien käsitykset ääntämisen ja fonetiikan tärkeydestä osana kielenopetusta sekä ääntämisen opetuksen ja arvioinnin nykyiset käytänteet. Tutkimme myös, mitkä tekijät vaikuttavat ääntämisen opetukseen ja haluamme selvittää erityisesti foneettisen koulutuksen riittävyyttä ja sen vaikutusta kokemukseen ääntämisen opetuksesta. Tieto nykyisistä toimintatavoista on tärkeää, koska sen perusteella opettajankoulutusta voidaan kehittää siten, että sen sisällöissä huomioidaan paremmin ääntämisen opettaminen.

\section{Aineisto ja menetelmät}

\section{Aineisto ja analyysimenetelmät}

Kieltenopettajille suunnattiin keväällä 2018 kyselytutkimus, jolla kartoitettiin, miten heidän oma koulutuksensa on valmistanut heitä ääntämisen opettamiseen, sekä miten ääntämistä opetetaan ja arvioidaan tällä hetkellä. Ensisijaisena kohderyhmänä olivat suomalaisissa peruskouluissa ja lukioissa toimivat kieltenopettajat, mutta kysely oli avoin kaikille kieltenopettajille. Kyselystä tiedotettiin Suomen kieltenopettajien liitto ry:n (SUKOL) jäsenlehti Tempuksessa julkaistussa artikkelissa (Virkkunen, 2018), SUKOLin Facebook-sivulla sekä kieltenopettajien piiriyhdistysten kautta. Pääkaupunkiseudulla tehtiin neljä ääntämisen opettamiseen keskittynyttä kouluvierailua, joiden aikana kerrottiin kyselystä, ja lisäksi suurimpien kaupunkien yläkouluihin ja lukioihin (yhteensä noin 70 koulua) lähetettiin sähköpostitse tiedote tutkimuksesta. Vastaajien kesken arvottiin viisi kirjapalkintoa. 
Kyselylomake oli Helsingin yliopiston e-lomake. Lomakkeen 43 kysymystä jakautuivat viiteen pääteemaan: vastaajan taustatiedot, vastaajan oman koulutuksen sisällöt, nykyiset opetuskäytänteet, nykyiset arviointi- ja palautteenantokäytänteet sekä täydennyskoulutuksen tarve. 16 kysymyksessä vastaajan oli mahdollista tarkentaa vastaustaan avoimessa kentässä. Kyselyn pohjana käytettiin EPTiES-hankkeen kyselylomaketta (Henderson ym., 2015), jota muokattiin ja siihen lisättiin fonetiikkaa ja eksplisiittistä ääntämisen opetusta koskevia kysymyksiä. Lähes kaikkiin kysymyksiin vastattiin asteikolla $1-4$, jossa 1 tarkoitti vaihtoehtoa "ei lainkaan" ja 4 "erittäin paljon". Keskimmäinen, neutraali vaihtoehto jätettiin tarkoituksella pois, koska halusimme selvittää erityisesti asenteita ja mielipiteitä. Toivoimme näin saavamme kaikilta vastaajilta mielipiteen jompaankumpaan suuntaan. Käytetty asteikko on toki suppea eikä se siten erottele vastauksia kovin tarkasti. Toisaalta käytettäessä esimerkiksi seitsenasteista Likert-asteikkoa vastaukset keskittyvät usein asteikon keskialueelle, eikä ääripäitä juuri käytetä (Guilford, 1954).

Tuloksia analysoitiin sekä määrällisiä että laadullisia menetelmiä käyttäen. Määrällisten tulosten kuvailussa käytettiin frekvenssi- ja prosentti- jakaumia sekä keski- ja hajontalukuja. Kahden ryhmän välisten erojen analysointiin käytettiin riippumattomien otosten t-testiä ja lisäksi muuttujien välisiä yhteyksiä tarkasteltiin Pearsonin korrelaatiokertoimen avulla. Käytettyihin opetusmenetelmiin vaikuttaneita seikkoja selvitettiin varianssianalyysin avulla.

Osa avoimista vastauksista valittiin tarkasteltavaksi induktiivisen sisällönanalyysin keinoin, jolloin vastaukset ryhmiteltiin sisällön mukaan ja tulokset muodostettiin aineiston perusteella. Tarkka sisällönanalyysi tehtiin niistä avoimista kysymyksistä, joilla selvitettiin IPAn käyttöä opetuksessa (eli opettiko opettaja IPAn teoriataustaa, merkkien lukemista tai kirjoittamista), palautteenantoa ja arviointia sekä opettajien toivomia täydennyskoulutuksen aiheita. Vastaukset luokiteltiin teemoittain, jolloin saatiin selville yleisimmät syyt esimerkiksi IPA-merkkien opettamatta jättämiselle.

\section{Vastaajat}

Kyselyyn vastasi 175 kieltenopettajaa (joista 169 aineenopettajaa). Vastaajat olivat iältään 25-62 -vuotiaita (keskiarvo 43 vuotta) ja heillä oli opetuskokemusta $1-35$ vuotta (ka 11-15 vuotta). 172 vastaajan äidinkieli oli suomi. Yleisimmin opetettavat kielet olivat englanti, jota opetti yli puolet vastaajista, ja ruotsi, jota opetti noin viidennes vastaajista. Opettajien ensisijaisesti opettamat kielet löytyvät taulukosta $1.60 \%$ vastaajista opetti kahta tai useampaa kieltä. Opettajien taustatietojen vaikutusta ei tässä tutkimuksessa tarkasteltu selittävänä tekijänä vastaajaryhmien epätasaisen kokojakauman vuoksi. 
Taulukko 1. Vastaajien ensisijaisesti opettamat kielet.

\begin{tabular}{l|c|c} 
& määrä & \% vastaajista \\
\hline \hline englanti & 97 & 55,4 \\
\hline ruotsi & 34 & 19,4 \\
\hline ranska & 13 & 7,4 \\
\hline saksa & 12 & 6,9 \\
\hline venäjä & 8 & 4,6 \\
\hline suomi toisena kielenä (S2) & 7 & 4,0 \\
\hline espanja & 4 & 2,3 \\
\hline \hline yhteensä & 175 & 100
\end{tabular}

Enemmistö vastaajista opetti ensisijaisesti lukiossa $(36,6 \%)$ tai yläkoulussa $(34,9 \%)$. Noin viidennes $(19,4 \%)$ opetti alakoulussa ja joka kymmenes $(9,1 \%)$ jossain muualla (mm. avoin yliopisto, ammattikorkeakoulu, ammattikoulu ja kansalaisopisto). Monet opettajat mainitsivat opettavansa sekä lukiossa että yläkoulussa.

Vastaajia oli kaikista Suomen opettajankoulutusta tarjoavista yliopistoista. Helsingin yliopistosta oli valmistunut $27,4 \%$ ja Jyväskylän yliopistosta $26,9 \%$ vastaajista. Seuraavaksi eniten valmistuneita oli Turun $(15,4 \%)$ ja Tampereen $(14,3 \%)$ yliopistoista. Lisäksi mainittiin ItäSuomen (7,4 \%) ja Oulun (4,6 \%) yliopistot sekä Åbo Akademi (1,7 \%). Muutama opettaja oli valmistunut ulkomaisista yliopistoista.

\section{Tulokset}

Ellei toisin mainita, kaikissa tuloksissa vastaajien määrä (n) on 175 ja numeerisissa kysymyksissä on käytetty asteikkoa $1-4$, jossa 1 = ei lainkaan riittävä tai ei lainkaan tärkeä ja 4 = täysin riittävä tai erittäin tärkeä.

\section{Vastaajien oma koulutus}

Ymmärrys puheentuoton foneettisesta perustasta auttaa ymmärtämään myös vieraan kielen ääntämistä ilmiönä. Koska tutkimuksessa haluttiin selvittää erityisesti fonetiikan osuutta kielenopettajien koulutuksessa, kysymyksenasettelussa pohjustettiin aihetta seuraavasti: "Fonetiikan opetus osana kieltenopettajien koulutusta on vaihdellut aikakausittain, yliopistoittain ja kielittäin. Tästä johtuen tarjotut opetusmäärät ja kurssien sisällöt ovat vaihdelleet koulutusajasta ja -paikasta riippuen. Miten riittävänä koet saamasi fonetiikan opetuksen määrän?” Opettajat pitivät oman koulutuksen aikana saamaansa fonetiikan opetuksen määrää pääosin melko riittävänä (keskiarvo 2,9, keskihajonta 0,9). Vastauksella haluttiin selvittää opettajan omaa kokemusta hänen saamansa opetuksen määrästä, joten emme kysyneet tarkemmin esimerkiksi kurssi- tai opintopistemääriä. Monet opettajat selvensivät kuitenkin kysymykseen liittyvässä avoimessa vastauskohdassa saamaansa opetusta ja sen laatua. Monesti opintoihin oli kuulunut yksi pakollinen yleisen fonetiikan kurssi sekä oman kieliaineen fonetiikan kursseja, jotka vastausten perusteella keskittyivät lähinnä oman ääntämisen harjoittamiseen. 
Opintojen sisältöihin oli kuulunut osin runsaastikin omaan ääntämiseen keskittyvää sekä kohdekielen äänteisiin ja intonaatioon liittyvää opetusta. Kuitenkin $86,2 \%$ vastaajista koki, ettei ollut saanut opettajankoulutuksessaan lainkaan tai vain vähän opetusta ääntämisen opettamisen menetelmistä: "Englannin opintoihin opetusta kuului hyvin ja paljonkin, mutta pedagogisiin ei-itselle helppojen asioiden erilaisia opetustapoja ei osannut opiskelijana kysellä." (vastaaja 111, kursivoidut lainaukset kyselyn avovastauksista) Moni vastaaja kertoikin opiskelleensa tutkintoon kuuluvien kurssien lisäksi fonetiikkaa itsenäisesti huomattuaan sen hyödyt opetustyössään. Ääntämistä tai sen opetusta käsittelevissä täydennyskoulutuksissa oli käynyt alle viidennes $(17,7 \%)$ vastaajista ja usein koulutus oli ollut vain yksittäinen luento opettajien täydennyskoulutuspäivien tai seminaarin aikana.

Lähes kaikkien vastaajien äidinkieli oli suomi, eli myös opettajat ovat ensin itse opiskelleet opettamansa kielen vieraana kielenä, ensin perusopetuksessa ja toisen asteen koulutuksessa ja myöhemmin korkeakoulussa. Opettajat arvioivat oman ääntämistaitonsa pääosin hyväksi. $97,1 \%$ vastaajista oli hyvin varma tai melko varma omasta ääntämistaidostaan, eikä kukaan ollut hyvin epävarma. Oman ääntämisen kehittymiseen oli vaikuttanut eniten oleskelu ulkomailla joko vaihdossa tai kieliharjoittelussa. Avovastauksissa nousivat muutenkin esille vahvasti oman koulutuksen ulkopuoliset tekijät: "Jokaisena opiskeluvuotena olisi pitänyt olla fonetiikan opetusta säännöllisesti. Itsenäisesti piti päivittää omia ääntämistaitojaan." (vastaaja 101) Vastaajat olivat kiinnostuneita ylläpitämään ja kehittämään omaa ääntämistään ja he toivat myös esille, miten tärkeää on tietoisuus kohdekielen äänteistä ja jatkuva huomion kiinnittäminen ääntämiseen ja kohdekielen muutoksiin. Vastauksissa varmuus omasta ääntämisestä korreloi positiivisesti etenkin koetun ääntämisen opettamisen helppouden $(r(173)=0,35, \mathrm{p}<0,001)$ ja omassa koulutuksessa saadun fonetiikan opetuksen määrän $(r(173)=0,23, \mathrm{p}<0,01)$ kanssa.

Vastaajat pitivät ääntämisen opetusta yleisesti tärkeänä; vastausten keskiarvo oli 3,8 (kh 0,4). Fonetiikan yhdistämistä kieltenopetukseen ei kuitenkaan pidetty samalla tavalla tärkeänä, keskiarvo 2,9 (kh 0,7). (Kuva 1.)

Kuva 1. Vastaajien arvio ääntämisen ja fonetiikan opetuksen tärkeydestä osana kielenopetusta. $1=$ ei lainkaan tärkeä, $2=$ ei kovin tärkeä, $3=$ melko tärkeä, $4=$ erittäin tärkeä.

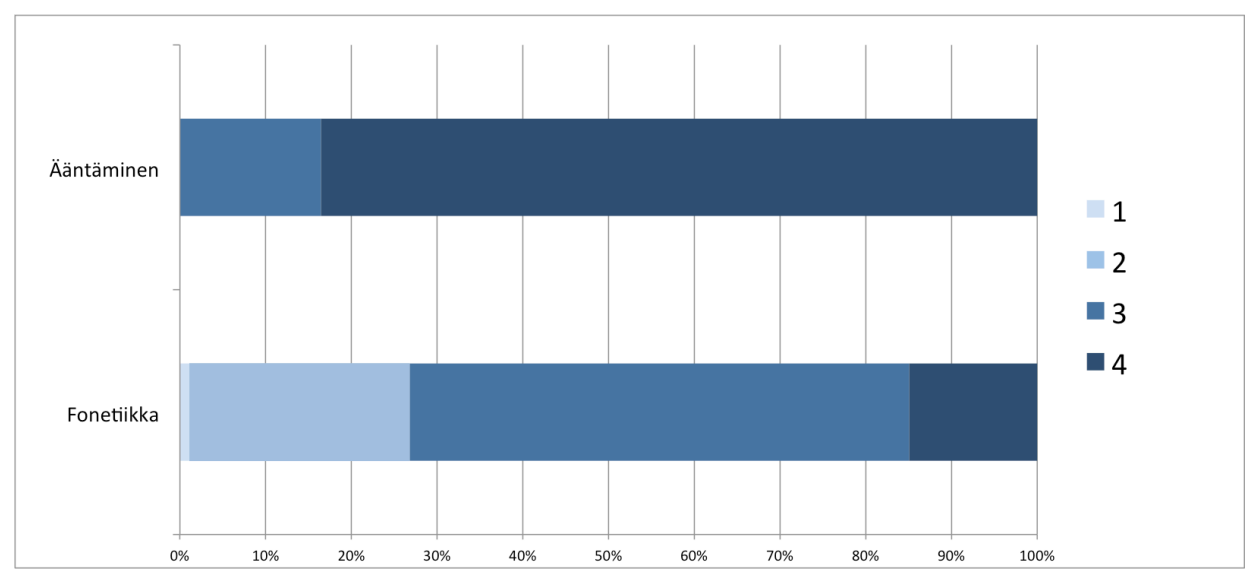


Opettajat pitivät ääntämisen opettamista pääosin melko helppona, mutta vastauksissa oli melko paljon hajontaa (ks. taulukko 2). Lähemmin tarkasteltuna opetuksen koetulla helppoudella oli yhteys erityisesti oman koulutuksen aikaisen fonetiikan opetuksen määrän kanssa $(r(173)=0,35$, $\mathrm{p}<0,001$ ). Enemmän (vastaukset $3 \mathrm{ja} 4 ; \mathrm{n}=70$ ) fonetiikan opetusta saaneet kokivat ääntämisen opettamisen helpommaksi (ka 3,3) kuin vähemmän (vastaukset $1 \mathrm{ja} 2 ; \mathrm{n}=105$ ) fonetiikan opetusta saaneet $(\mathrm{ka} 2,7)$. Ryhmien välinen ero osoittautui tilastollisesti erittäin merkitseväksi: $t(174)=-4.50, \mathrm{p}<0,001$.

Taulukko 2. Vastaajien arvio heidän omasta ääntämisestään ja oman koulutuksen foneettisista sisällöistä. Korrelaatio verrattu koettuun ääntämisen opettamisen helppouteen (taulukon ylimmäinen rivi). Kaikissa vastauksissa $n=175$, vastausvaihtoehdot oman koulutuksen sisältöjä koskien: 1 = ei lainkaan, $2=$ ei juurikaan, $3=$ melko paljon, $4=$ erittäin paljon.

\begin{tabular}{l|l|l|l|l} 
& $\begin{array}{l}\text { Kaikkien } \\
\text { vastausten } \\
\text { keskiarvo }\end{array}$ & $\begin{array}{l}\text { Kaikkien } \\
\text { vastaus- } \\
\text { ten kes- } \\
\text { kihajonta }\end{array}$ & $\begin{array}{l}\text { Korrelaatio } \\
\mathrm{r}\end{array}$ & $\begin{array}{l}\text { Korrelaation } \\
\text { tilastollinen } \\
\text { merkitsevyys }\end{array}$ \\
\hline $\begin{array}{l}\text { Oma arvio ääntämisen } \\
\text { opettamisen helppoudesta }\end{array}$ & 3,10 & 0,83 & & \\
\hline $\begin{array}{l}\text { Oma koulutus: fonetiikan } \\
\text { opetuksen riittävyys }\end{array}$ & 2,86 & 0,89 & 0,352 & $\mathrm{p}<0,001$ \\
\hline $\begin{array}{l}\text { Oma koulutus: yleisen } \\
\text { fonetiikan opetuksen } \\
\text { määrä }\end{array}$ & 2,42 & 0,67 & 0,299 & $\mathrm{p}<0,001$ \\
\hline $\begin{array}{l}\text { Oma koulutus: oman } \\
\text { äidinkielen ja kohdekielen } \\
\text { erojen tarkastelu }\end{array}$ & 2,40 & 0,93 & 0,203 & $\mathrm{p}<0,001$ \\
\hline $\begin{array}{l}\text { Oma koulutus: oman } \\
\text { ääntämisen kehittyminen }\end{array}$ & 2,65 & 0,92 & 0,280 & $\mathrm{p}<0,001$ \\
\hline $\begin{array}{l}\text { Oma arvio ääntämistai- } \\
\text { dosta (epävarma - varma) }\end{array}$ & 3,46 & 0,55 & 0,352 & $\mathrm{p}<0,001$ \\
\hline $\begin{array}{l}\text { Oma koulutus: saiko tietoa } \\
\text { foneettisesta aakkostosta } \\
\text { (IPA) }\end{array}$ & 2,94 & 0,89 & 0,218 & $\mathrm{p}<0,001$ \\
\hline $\begin{array}{l}\text { Oma koulutus: prosodiset } \\
\text { sisällöt (esim. intonaatio, } \\
\text { paino) }\end{array}$ & 2,79 & 0,78 & 0,324 & $\mathrm{p}<0,001$ \\
\hline $\begin{array}{l}\text { Oma koulutus: ääntämisen } \\
\text { opettamisen menetelmät }\end{array}$ & 1,73 & 0,78 & 0,265 & $\mathrm{p}<0,001$ \\
\hline
\end{tabular}

\section{Ääntämisen opetusmenetelmät}

Ääntämisen opetusmenetelmiä koskevan osion kysymyksissä vastaajat valitsivat annetuista vaihtoehdoista käyttämiään menetelmiä ja arvioivat niiden käytön määrää. Vastausta saattoi tarkentaa avokentässä. Käytetyt ääntämisen opettamisen menetelmät sekä vastausten keskiarvot ja -hajonnat ovat taulukossa 3. 
Äänteiden ja prosodian harjoitteluun opettajat käyttivät eniten ääneen lukemista, yleensä parin kanssa tai niin sanottuna sorinalukuna. Muita käytettyjä menetelmiä olivat ääntämisdrillit, rytmi- ja intonaatioharjoitukset ja yhdessä laulaminen. Osa opettajista mainitsi avovastauksissa erilaiset kielitietoisuutta lisäävät harjoitukset, kuten äänteiden vertailut sekä ääntämisharjoitukset, joissa kiinnitetään huomiota ääntöväylän asentoon, soinnillisuuteen ("sormet kaulalla") tai aspiraatioon (paperi tai kämmen suun edessä). Laulamisen on havaittu tukevan kielenoppimista sen kaikilla osa-alueilla (ks. esim. Alisaari, 2016; Good, Russo \& Sullivan, 2015; Ludke, Ferreira \& Overy, 2014; Mora, 2000). Laulun hyödyntäminen opetusmenetelmänä korreloi kuitenkin vahvasti opetusasteen kanssa $(r(173)=0,40, \mathrm{p}<0,001)$; alakoulun opettajat kertoivat laulavansa tunneilla paljon, kun taas yläkouluissa ja lukioissa laulettiin hyvin vähän, jos ollenkaan. Avovastausten perusteella myös niin sanottuja tongue twistereitä, riimittelyä ja loruttelua harjoiteltiin etenkin nuorimpien oppilaiden kanssa.

Ääntämisen opetuksessa vastaajat käyttivät eniten apunaan oppikirjoja; lähes 70 \% vastaajista käytti oppikirjoja runsaasti. Muina ääntämisen opetuskeinoina tuotiin esille muun muassa keskusteluharjoitukset pareittain, opiskelijoiden pitämät suulliset esitelmät sekä onlinemateriaalit (mm. Quizlet-harjoitukset). Ääntämisen mallina toimi opettaja itse tai äänite natiivipuhujalta. Runsas vieraskielisen puheen kuuntelu, mielellään useilta eri puhujilta, kehittää oppijaa erottelemaan kuulemiaan äänteitä ja prosodisia sävelkulkuja sekä herkistää ymmärtämään erilaisia aksentteja (Lintunen, 2014). Avovastauksissa esille nousivat muun muassa kuuntelu- ja tunnistustehtävät ("merkitse kuulemasi äänne/sana" tai "piirrä intonaatiokaava"). Opettajat kertoivat käyttävänsä kuunteluharjoituksiin erilaisia online -materiaaleja (kuten vlogit, podcastit, Youtube-videot ja kieltenopiskeluun tarkoitetut verkkosivustot) sekä DVD- ja CD-levyjä. Nämä ovatkin hyviä lähteitä spontaanin natiivipuheen kuulemiseen, toki niitä käytettäessä kannattaa muistaa lähdekriittisyys; puhujasta ja hänen taustastaan ei yleensä ole mitään tietoja, ja äänitteen laatu saattaa olla vaihtelevaa.

Taulukko 3. Opettajien käyttämien ääntämisen opettamisen menetelmien ja apuvälineiden yleisyys. Kaikissa vastauksissa $n=175$. Vastausvaihtoehdot opetusmenetelmiä koskien: $1=$ ei lainkaan, $2=$ ei juurikaan, $3=$ melko paljon, 4 = erittäin paljon.

\begin{tabular}{l|l|l} 
Ääntämisharjoitukset & Keskiarvo & Keskihajonta \\
\hline \hline Ääntämisdrillit & 2,76 & 0,88 \\
\hline Rytmi- ja intonaatioharjoitukset & 2,65 & 0,79 \\
\hline Ääneen lukeminen & 3,58 & 0,64 \\
\hline Yhdessä laulaminen & 2,39 & 1,13 \\
\hline Sanaston IPA-merkkeihin tutustuminen & 2,21 & 0,82 \\
\multirow{2}{*}{ Opetuksen apuna käytetään } & & \\
\hline \hline Oppikirjat & & \\
\hline
\end{tabular}


Ainedidaktiikka 4(1) (2020)

\begin{tabular}{l|l|l}
\hline Sanakirjat & 1,70 & 0,80 \\
\hline CD/DVD & 2,78 & 1,07 \\
\hline Oman puheen äänittäminen & 2,39 & 0,91 \\
\hline Online materiaalit & 2,60 & 1,01
\end{tabular}

Suomessa tehdyt oppikirja-analyysit (Heinonen, tulossa; Tergujeff, 2010) paljastavat, että suuri osa oppikirjojen harjoitustehtävistä liittyy yksittäisten sanojen tai äänteiden tuottoon. Myös näissä vastauksissa korostui yksittäisten sanojen ääntäminen, laajempien prosodisten kokonaisuuksien harjoittelun jäädessä vähemmälle. Opetuksessaan opettajat painottivat ääntämisen osa-alueita yleisyysjärjestyksessä seuraavasti (kuva 2): sanat (ka 3,6/kh 0,6), yksittäiset äänteet $(3,1 / 0,8)$ ja prosodia $(2,9 / 0,8)$. Ero sanojen ja prosodian opetuksen määrien välillä oli tilastollisesti erittäin merkitsevä $t(174)=13,70, \mathrm{p}<0,001$. Tulokset myös osoittivat, että prosodian opetuksen määrää korreloi positiivisesti sen kanssa, miten helppona opettaja piti ääntämisen opettamista $(r(173)=0,37, \mathrm{p}<0,01)$.

Kuva 2. Eri ääntämisen osioiden (sanat, yksittäiset äänteet, prosodia) opettamisen yleisyys. $1=$ ei lainkaan, $2=$ ei juurikaan, $3=$ jonkin verran, $4=$ runsaasti.

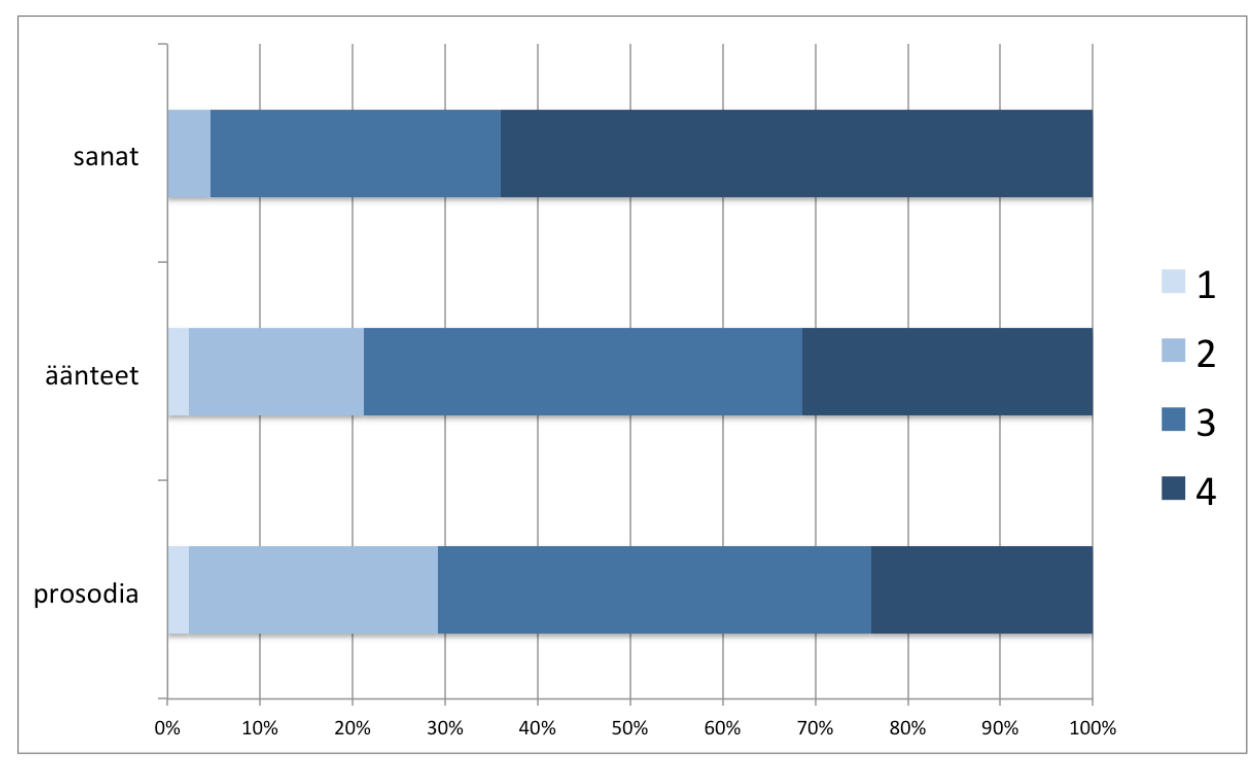

\section{Foneettinen kirjoitus}

Foneettista kirjoitusta koskevan osion kysymyksissä selvitettiin, kuinka paljon opettajat hyödynsivät opetuksessaan IPAn teoreettista taustaa ja opettivat sen lukemista ja kirjoittamista. IPAn käyttöä tarkasteltiin numeeristen arvojen lisäksi myös avovastausten perusteella. Opettajien vastaukset luokiteltiin ryhmittäin ja niiden perusteella muodostettiin käsitys IPAn hyvistä ja huonoista puolista opetuksessa sekä opettajien asenteista sen käyttöä kohtaan.

Kysymys "Opetatko IPA-taulukon teoreettista taustaa?" oli taustoitettu seuraavalla tekstillä: "Esim. vokaalin laadun määrittävät kielen korkein kohta suuontelossa akseleilla suppea-väljä ja etinen-takainen sekä 
huulten asento (pyöreä vs. lavea). Vokaaleja havainnollistaa vokaalinelikulmio, joka symboloi kielen korkeinta kohtaa suuontelossa. Konsonanttien kohdalla äänteen paikka IPA-taulukossa kertoo suoraan sen artikulaatiopaikan ja -tavan sekä äänteen soinnillisuuden / soinnittomuuden." Vastausten (kuva 3) perusteella IPAn taustaa ei opeteta juuri lainkaan (ka 1,4/kh 0,6). Suurimpana syynä tähän mainittiin ajan puute. Opettajat pitivät aihetta myös liian teoreettisena koulutasosta riippumatta, eli saman vastauksen antoivat niin ala- ja yläkoululaisten kuin lukiolaistenkin opettajat. Lisäksi monet vastaajat kertoivat, että he eivät muista, miten IPA-taulukkoa luetaan. "Vaikeus on lähinnä siinä, etten osaa välttämättä kuvata, missä asennossa kielen pitäisi olla tms. jonkun äänteen kohdalla." (vastaaja 12)

IPA-merkkien tunnistamista tai lukemista opetettiin vähän $(2,3 / 0,8)$. Vastaajat tunnistivat IPAn hyödyt kuitenkin opettaessaan kieltä, jonka kirjain-äänne-vastaavuus on heikko: "Auttaa myös tekemään eroa lähtökielen ja kohdekielen äänteiden välillä, kun eri äänteille on omat symbolit, jotka eivät ole sidoksissa ortografiaan." (vastaaja 7) Opettajat myös korostivat IPAn tärkeyttä oppijoiden itsenäisen kielenopiskelun apuna. "Merkkien ymmärtäminen on tärkeää, jotta opiskelijat voivat itse selvittää sanojen äänneasuja." (vastaaja 38)

IPAn kirjoittamista pidettiin vaikeampana kuin tunnistamista, eikä sitä opetettu lähes ollenkaan $(1,3 / 0,5)$. Seuraava lainaus kiteytti monen opettajan ajatukset:

En tiedä mitä hyötyä foneettisten aakkosten kirjoittamisesta olisi? En koe muistavani tarpeeksi asiasta vaikka olen kyllä huomannut, että foneettiset aakkoset ovat useahkolle opiskelijalle tuntemattomia/eivät osaa niitä käyttää. En itse ole jaksanut muun työn ohella itse perehtyä IPAan uudestaan. (vastaaja 75)

Toisaalta osa opettajista oli työssään havainnut, että merkeistä voi hyötyä, vaikka niistä opeteltaisiin vain osa: "Merkitsemme tekstissä oleviin sanoihin äännemerkkejä, niin että lukeminen tulisi sujuvammaksi ja merkit tutuiksi lapsille." (vastaaja 97) 
Kuva 3. Kuinka paljon opettajat käyttävät IPAa ääntämisen opetuksen apuna? 1 = ei lainkaan, 2 = ei juurikaan, 3 = jonkin verran, $4=$ runsaasti.

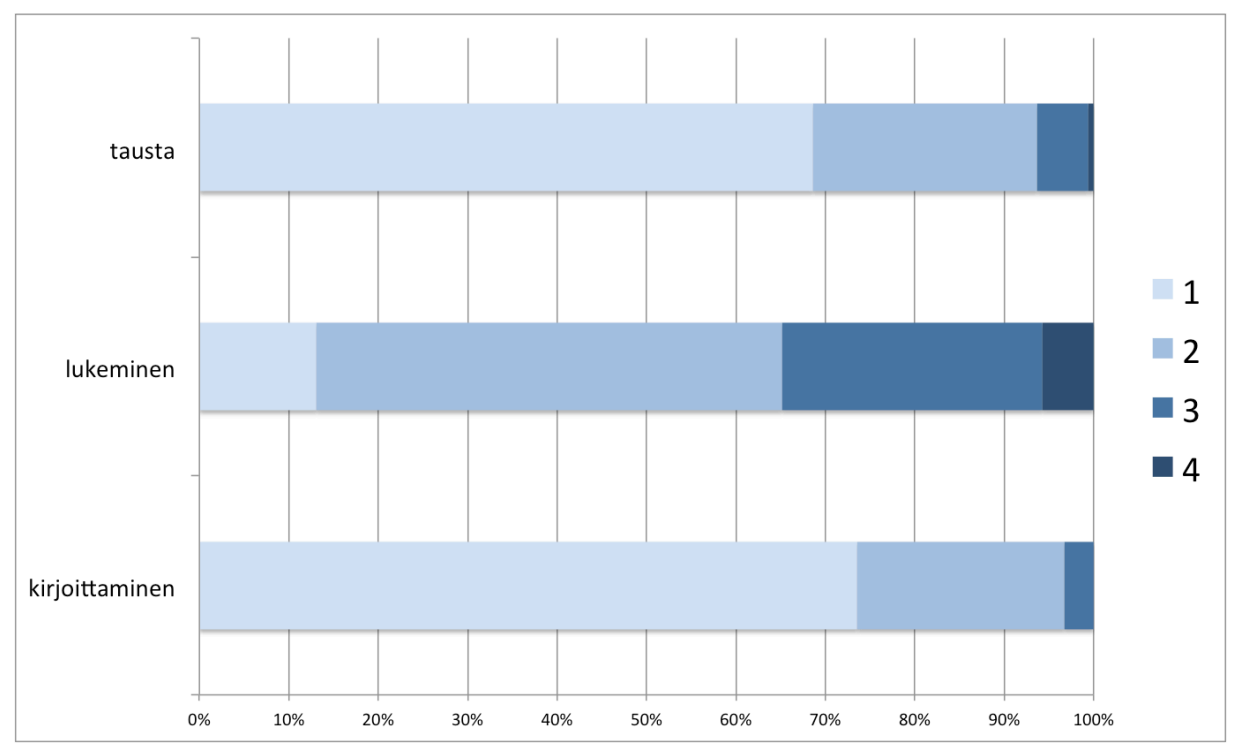

Osa vastaajista kertoi, että IPA on jäänyt tarpeettomaksi digitaalisten nettisanakirjojen yleistymisen myötä, sillä välillä niissä tarjotaan myös ääntämismalli sanasta. Avovastauksista nousi myös esille opettajien oletus, että joku muu on jo opettanut tai opettaa myöhemmin IPA-merkit: "Oletan, että alakoulussa niitä on harjoiteltu." (vastaaja 62) "Oppilaat ovat jo tutustuneet niihin englannin opinnoissa, ruotsin tunneilla varmistan vain osaamisen." (vastaaja 158)

\section{Ääntämisen arviointimenetelmät}

Ääntämisen arviointimenetelmiä ja palautteenantoa koskevan osion kysymyksissä vastaajat valitsivat annetuista vaihtoehdoista käyttämiään menetelmiä ja arvioivat niiden käytön määrää. Vastausta saattoi tarkentaa avokentässä. Käytetyt ääntämisen arvioinnin menetelmät sekä vastausten keskiarvot ja -hajonnat ovat taulukossa 4.

Ääntämisen arvioinnissa opettajat käyttivät eniten apuna kuullunymmärtämistehtäviä. Myös ääneen lukemista ja suullisia harjoituksia, kuten keskusteluja ja esitelmiä, käytettiin paljon. Suullisia kokeita käytettiin selvästi vähemmän. Vaikka ääntämistä pidettiin tärkeänä osana kielitaitoa, sillä oli silti vain vähän painoarvoa kokonaisarvioinnissa. Ääntämistä ei arvioitu tarkemmin tunneilla (englannin suullisen kielitaidon ENA8-kurssia lukuun ottamatta), koska ääntämistaitoa ei tarvita ylioppilaskokeessa, jossa ei erikseen testata suullista kielitaitoa. Opettajat toivat esille, että "Opiskelijoiden tulee saada pätevää opetusta kaikkiin osa-alueisiin, joita ylioppilaskoe testaa" (vastaaja 66), mikä tukee aiempia havaintoja siitä, että arviointi ohjaa vahvasti opetusta (esim. Hamp-Lyons, 2007; Pohjala, 2004). Yleensä heikkokaan ääntäminen ei alentanut arvosanaa, tosin eräs opettajista totesi, että "Kympin oppilaan on äännettävä hyvin, pelkkä kirjallinen osaaminen ei auta." (vastaaja 99)

Suurin osa opettajista antoi jonkin verran palautetta oppijoille heidän ääntämisestään. "'Annan palautetta] jotta he tulisivat omista taidoistaan tietoisiksi ja voisivat kehittyä." (vastaaja 116) Avovastausten mukaan 
opettajien on helppo antaa positiivista palautetta, mutta etenkin luokkatilanteessa korjaamista vältetään. Oppijat arastelevat herkästi omaa puhettaan ja korjaava palaute saattaa vaientaa ujoimmat opiskelijat kokonaan. Ilolan (2020) mukaan monet oppijat haluavat kuitenkin oppia paremmiksi ääntäjiksi ja toivovat saavansa myös korjaavaa palautetta, joten opettajien ei kannata alkaa liian varovaisiksi palautteenannossaan.

Varovaisuudestaan huolimatta opettajat toivat vastauksissaan esille, että ääntäminen on tärkeää puheen ymmärrettävyyden takia ja he halusivat siksi korjata virheet, jotka vaikuttivat eniten ääntämiseen ja toistuivat yleisimmin. "Korjaamalla omaa ääntämistään opiskelija oppii ja näin tulee varmemmaksi ja rohkeammaksi kielenkäyttäjäksi." (vastaaja 107) Oppijat tekivät usein luokassa pareittain puhe- ja keskusteluharjoituksia, joita opettaja kiersi kuuntelemassa. Korjaavan palautteen antaminen sisällytettiin tilanteisiin, joissa se saatiin luontevasti yleistettyä useammalle puhujalle. Avovastausten perusteella opettajat käyttivät yhä enemmän suullisia tehtäviä, joissa oppijat tekivät kotona äänitteen tai videon, jonka palauttivat opettajalle. Näistä opettajat myös antoivat arvokasta henkilökohtaista palautetta, joka muuten luokkatilanteessa jäi vähäiseksi.

Taulukko 4. Opettajien antaman palautteen määrä ja ääntämisen arvioinnin menetelmät. Kaikissa vastauksissa $n=175$. Vastausvaihtoehdot $1=$ ei lainkaan, 2 = ei juurikaan, $3=$ jonkin verran, $4=$ runsaasti.

\begin{tabular}{l|l|l} 
& Keskiarvo & Keskihajonta \\
\hline \hline Ääntämisen painoarvo kokonaisarvioinnissa & 2,15 & 0,53 \\
\hline Annetun palautteen määrä & 2,65 & 0,70 \\
\hline \hline $\begin{array}{l}\text { Arvioinnin apuna käytetyt tehtävät } \\
\begin{array}{l}\text { Kirjalliset tehtävät, esim. IPAn lukemista / kirjoitta- } \\
\text { mista }\end{array}\end{array}$ & 1,30 & 0,52 \\
\hline Suulliset esitykset, esim. esitelmät & 2,91 & 0,79 \\
\hline Suullinen koe parille & 2,42 & 0,94 \\
\hline Suullinen koe yhdelle & 2,02 & 0,94 \\
\hline Kuullunymmärrämistehtävät & 3,31 & 0,79 \\
\hline Ääneen lukeminen & 2,97 & 0,90 \\
\hline
\end{tabular}

\section{Täydennyskoulutus}

Enemmistö kyselyn vastaajista $(64,6 \%)$ koki tarvitsevansa täydennyskoulutusta ääntämisen opettamisesta. Vastauksiin saattoi vaikuttaa tieto siitä, että ylioppilaskokeisiin suunnitellaan suullisen kielitaidon kokeita. (Kyselyä tehtäessä ensimmäiset kokeet oli suunnitelmissa aloittaa neljän vuoden kuluttua, vuonna 2022.) Vastaukset korreloivat opetusasteen kanssa $(r(173)=-0,27, \mathrm{p}<0,001)$; lukion opettajista lähes $80 \%$ toivoi täydennyskoulutusta, kun alakoulun opettajista vastaava toive oli vain $50 \%: 11$. Kysymyksenasettelussa mainitut ylioppilaskirjoitukset 
saattoivatkin ohjata vastaajien täydennyskoulutukseen liittyvät ajatukset vain lukion suuntaan.

Täydennyskoulutusta opettajat toivoivat eniten workshoptyyppisten, lyhyiden koulutusjaksojen muodossa (ka 3,2/kh 0,9). Verkkokurssit koulutusmuotona saivat vähemmän kannatusta, tosin vastauksissa oli melko runsaasti hajontaa $(2,5 / 1,2)$. Verkossa tapahtuvan opetuksen etuna on sen saavutettavuus; koulutukseen voi osallistua helposti työpaikalla tai kotona, ja verkko-opintoja voi tehdä itselleen sopivana ajankohtana. Opettajia kuitenkin mietitytti verkko-opetuksessa vertaistuen puute, sillä he kokivat, että suuri osa koulutuksen hyödyistä saatiin yhteisistä keskusteluista muiden kanssa.

Pääteemat, joissa opettajat toivoivat täydennyskoulusta, olivat ääntämisen opetus yleisesti, opetusmenetelmät ja -materiaalit ja käytännön vinkit sekä ääntämisen arviointi. Erityisesti tulossa oleva suullisen kielitaidon koe herätti kysymyksiä. Huolta opettajissa herätti se, että toistaiseksi ei ole tiedossa, millainen ylioppilaskokeiden suullinen koe tulee olemaan ja miten siinä painotetaan esimerkiksi ääntämistä, prosodista osaamista ja vuorovaikutusta. Opettajat pitivät myös tärkeänä sitä, että heillä on keinot opettaa opiskelijoitaan parhaalla mahdollisella tavalla: "Ylioppilaskokeita varten pitäisi aina saada koulutusta, jos opettaa niihin tähtääviä opiskelijoita. Siten varmistetaan parhaat mahdolliset tulokset opiskelijoille." (vastaaja 38)

\section{Pohdinta}

Kiinnostus ääntämisen opetuksen teemoja kohtaan on herännyt sekä ylioppilastutkintoon suunnitteilla olevan suullisen kielitaidon kokeen että kielenopetuksen varhentamisen myötä, ja keskustelua käydään niin kieltenopettajakoulutuksessa kuin kentällä työskentelevien kieltenopettajienkin keskuudessa. Tässä tutkimuksessa selvitimme suomalaisissa kouluissa työskentelevien kieltenopettajien foneettisen koulutuksen riittävyyttä ja sen vaikutusta kokemukseen ääntämisen opetuksesta. Lisäksi tutkimme ääntämisen opetuksen ja arvioinnin nykyisiä käytänteitä. Kysely tehtiin keväällä 2018 ja siihen vastasi 175 opettajaa, jotka opettivat vieraita kieliä pääasiassa suomalaisissa yläkouluissa ja lukioissa. Taustatietojensa perusteella vastaajat edustivat kattavasti suomalaisia kieltenopettajia sekä opetettavan kielensä, koulutuksensa että opetuskokemuksensa suhteen. Toki tulee huomioida, että tämänkaltaisiin vapaaehtoisuuteen perustuviin kyselyihin vastaavat herkemmin opettajat, jotka ovat aiheesta muutenkin kiinnostuneita, mikä saattaa heijastua kyselyn tuloksiin.

Tämän tutkimuksen perusteella kieltenopettajille oli opetettu riittävästi ääntämistä, ja vastaajat olivatkin varmoja omasta ääntämistaidostaan. Sen sijaan he kokivat, etteivät olleet omassa koulutuksessaan saaneet riittävästi tietoa ääntämisen opettamisesta. He erottelivat vastauksissaan oman kohdekielensä opetuksen ja opettajankoulutuksen kertoen, että pedagogisista opinnoista oli puuttunut kaikki ääntämisen opetukseen liittyvä sisältö. Tulokset ovat olleet samankaltaisia myös aiemmissa tutkimuksissa (esim. Burgess \& Spencer, 2000; Huensch, 2018; MacDonald, 2002; Tergujeff, 2013; Uchida \& Sugimoto, 2019). 
Vastaajilla oli yhteinen käsitys siitä, että ääntämisen opetus oli tärkeä osa kieltenopetusta. Ääntämistä tulisi tutkimusten mukaan opettaa eksplisiittisesti, sillä oppijoiden lisääntynyt kielitietoisuus tukee kielenopiskelua ja helpottaa ääntämiselle tärkeiden motoristen taitojen oppimista (Derwing, Munro \& Wiebe, 1998; Dörnyei, 2009; Lintunen, 2014). Jos ääntäminen on opettajalle itselleen helppoa, mutta hänellä ei ole tietoa siitä, miten sitä opetetaan muille, saattaa opetus kuitenkin jäädä implisiittiseksi. Tutkimuksen merkittävä tulos oli, että opettajat kokivat ääntämisen opettamisen helpoimmaksi silloin, kun he tunsivat saaneensa omassa koulutuksessaan riittävästi fonetiikan opetusta. Koulutuksessaan enemmän fonetiikan opetusta saaneiden ryhmä koki ääntämisen opettamisen helpommaksi kuin vähemmän fonetiikan opetusta saaneiden ryhmä. Ryhmien välinen ero on tilastollisesti erittäin merkitsevä. Opettajat, jotka kokivat ääntämisen opettamisen helpoksi, opettivat myös enemmän prosodiaa, joka on puheen ymmärrettävyydelle tärkeä osa-alue (Derwing \& Munro, 2005; Derwing, Munro \& Wiebe 1998; Hahn, 2004).

Kyselyn vastaukset osoittivat, että IPAa ei juurikaan hyödynnetty opetuksessa, joten tilanteessa ei ollut tapahtunut muutosta viime vuosina (Tergujeff, 2013). IPAa voitaisiin käyttää visuaalisena apuvälineenä linkittämään ääntöväylän liikkeet äänteisiin. Koko IPA-aakkoston ulkoa osaaminen on tarpeetonta usein vielä yliopistotason lingvistiikan opetuksessakin, mutta riittävä IPAn hallinta voi tarjota opettajalle kaivattua itseluottamusta ääntämisen opetukseen (Burri, Baker \& Chen, 2017). Ääntämisen opetus muuttuu eksplisiittisemmäksi, kun ymmärretään ääntöväylän liikkeiden vaikutus tuotettujen äänteiden laatuun ja tehdään myös oppijat tietoiseksi tästä. Esimerkiksi [u] ja [y] eroavat toisistaan sen perusteella, miten edessä tai takana kieli on suussa niitä äännettäessä. Tämänkaltaisen foneettisen perustiedon avulla voidaan helposti lisätä ymmärrystä puheentuotosta oppijan iästä riippumatta.

Digitaalisten nettisanakirjojen ja niiden sisältämien ääntämismallien yleistymisen myötä IPA koetaan opetuksessa entistä useammin tarpeettomaksi. Ongelmia kuitenkin syntyy, jos oppija ei pysty tunnistamaan kuulemiaan kohdekielen äänteitä oikein. Näin tapahtuu helposti esimerkiksi silloin, kun äidinkielen ja kohdekielen äänteet ovat hyvin lähellä toisiaan (Best \& Tyler, 2007), jolloin äidinkielen aivoihin muodostamat muistijäljet toimivat ikään kuin havaintomagneetteina, jotka vetävät kohdekielen äänteitä puoleensa (ks. esim. Lintunen, 2014). Tällöin kohdekielessä esiintyvä äänne kuullaankin äidinkielisen äänteen mukaisena ja sanan ääntäminen opitaan virheellisesti, jolloin jopa sen merkitys voi muuttua.

Tuoreen tapaustutkimuksen mukaan suomalaiset peruskoulun yhdeksäsluokkalaiset $(n=9)$ pitävät ääntämistä, ja nimenomaan äänteiden hallintaa, tärkeimpänä englannin suullisen kielitaidon osana (Ilola, 2020). Tämän tutkimuksen vastaajat käyttivät ääntämisen opetuksen apuna eniten oppikirjoja, kuten myös opettajat Tergujeffin (2012) ja Luukan ja kumppaneiden (2008) tutkimuksissa, mutta oppikirjat sisältävät harvoin kattavasti kaikkia ääntämisen osa-alueita harjoittavia tehtäviä. Tämä olisikin asia, johon oppikirjojen tekijöiden olisi hyvä kiinnittää jatkossa enemmän huomiota. Hyvin suunniteltu ja vaihteleva opetus ylläpitää oppijan mielenkiintoa ja lisää motivaatiota harjoitteluun, ja opettajat 
käyttävätkin oppikirjojen lisäksi myös paljon omaa ja verkosta löytämäänsä materiaalia ääntämisen opetuksessaan.

Kyselyyn vastanneet opettajat olivat motivoituneita ylläpitämään ammattitaitoaan, kouluttautumaan ja uudistamaan opetuskäytäntöjään. "Minusta on mukava opettaa ääntämistä, mutta koen tarvitsevani lisätietoa ja vinkkejä opetukseen, jotain "kättä pidempää"." (vastaaja 30) Toisaalta kysely herätteli opettajia myös pohtimaan omia opetustapojaan: "Olen kai ajatellut, että oppilaille riittäisi ääntämisen harjoittelu kuulemisen ja näkemisen (suun asento) avulla. Ehkä näin ei ole.” (vastaaja 132) Opetus- ja kulttuuriministeriön selvityksen mukaan kieltenopettajille tarjotaan suhteellisen vähän kielididaktista täydennyskoulutusta ja opettajien mukaan siihen osallistuminen on hankalaa (Pyykkö, 2017, s. 116). Täydennyskoulutuksen kehittämisen lisäksi yliopistojen tehtävä olisikin tarjota kieltenopettajaopiskelijoille monipuolista ääntämisen opetukseen liittyvää koulutusta, joka on tehokasta ja perustuu uusimpaan tutkimukseen. Foneettista tietoisuutta lisäävä ja ääntämisen opettamiseen keskittyvä koulutus hyödyntää yhtälailla niin kieltenopettajaopiskelijoita kuin valmiita opettajiakin (Burri, Baker \& Chen, 2017).

Aikaisempaa varhemmin alkavan kielenopetuksen vuoksi entistä useammat opettajat tarvitsevat lisää tietoa puheesta, vieraan kielen oppimisesta ja ääntämisen opetuksesta. Jo ennen kouluikää valtaosa lapsista on ollut mukana varhaiskasvatuksen toiminnassa. Varhaiskasvatuksen perusteet (Opetushallitus, 2019) edellyttävät lapsen kielellisten taitojen ja valmiuksien sekä kielellisen identiteetin vahvistamista. Siten myös varhaiskasvattajat tarvitsevat entistä enemmän tietoa lapsen kielenkehityksestä, monikielisyydestä ja kielitietoisuuden tukemisesta (Sopanen, 2018). Jo ennen vieraan kielen opetuksen alkamista olisi tärkeää tehdä lapset tietoiseksi kielistä. Kielitieto on opetettavissa olevaa tietoa siitä, millaisia kieliä on olemassa, miten kielet vaikuttavat toisiinsa ja mikä on niiden merkitys ihmiselle (Lehtonen \& Räty, 2018). Kielitieto luo lapsille tärkeän pohjan, jonka päälle vieraan kielen taito rakentuu.

Varhentamisen myötä ensimmäinen vieras kieli on alkanut kaikilla oppilailla ensimmäisellä luokalla tammikuussa 2020 (Opetus- ja kulttuuriministeriö, 2018). Tutkimusten mukaan vieraan kielen ääntäminen opitaan sitä helpommin, mitä nuorempana harjoittelu aloitetaan, mikä vahvistaa varhain aloitetun kielenopiskelun tärkeyden ääntämiselle. Jatkossa tutkimusta tulisi laajentaa myös näihin nuorimpiin kielenoppijoihin, jotta ymmärrettäisiin paremmin ääntämisen oppimismekanismeja ja opetusmetodeja opetettaessa lapsia, joilla ei vielä ole luku- tai kirjoitustaitoa.

\section{Lähteet}

Alisaari, J. (2016). Songs and poems in the second language classroom. The hidden potential of singing for developing writing fluency. (Väitöskirja). Turun yliopisto. http://urn.fi/URN:ISBN:978-951-29-6673-8

Bassetti, B. (2008). Orthographic input and second language phonology. Teoksessa T. Piske \& M. Young- Scholten (toim.), Input Matters in SLA (ss. 191-206). Clevedon, UK: Multilingual Matters. https://doi.org/10.21832/9781847691118-013 


\section{Ainedidaktiikka 4(1) (2020)}

Best, C. T. \& Tyler, M. D. (2007). Nonnative and second-language speech perception: Commonalities and complementarities. Teoksessa O-S. Bohn \& M.J. Munro (toim.), Language experience in second language speech learning: In honor of James Emil Flege (ss. 13-34). Amsterdam: John Benjamins Publishing Company. https://doi.org/10.1075/11lt.17.07bes

Bongaerts, T. (1999). Ultimate attainment in L2 pronunciation: The case of very advanced late L2 learners. Teoksessa D. Birdsong (toim.) Second language acquisition and the critical period hypothesis (ss. 133-159). Mahwah, New Jersey: Lawrence Erlbaum Associates

Bongaerts, T., Mennen, S. \& Slik, F. V. D. (2000). Authenticity of pronunciation in naturalistic second language acquisition: The case of very advanced late learners of Dutch as a second language. Studia Linguistica, 54(2), 298-308. https://doi.org/10.1111/1467-9582.00069

Burgess, J. \& Spencer, S. (2000). Phonology and pronunciation in integrated language teaching and teacher education. System, 28(2), 191-215. https://doi.org/10.1016/S0346-251X(00)00007-5

Burri, M., Baker, A. \& Chen, H. (2017). "I feel like having a nervous breakdown": Preservice and in-service teachers' developing beliefs and knowledge about pronunciation instruction. Journal of Second Language Pronunciation, 3(1), 109135. https://doi.org/10.1075/jslp.3.1.05bur

Burri, M., Baker, A. \& Chen, H. (2018). Establishing a framework for learning to teach English pronunciation in an Australian TESOL program. Australian Review of Applied Linguistics, 41(3), 307-327. https://doi.org/10.1075/aral.18020.bur

Couper, G. (2003). The value of an explicit pronunciation syllabus in ESOL teaching. Prospect, 18(3), 53-70.

DeKeyser, R. M. (2018). Age in learning and teaching grammar. Teoksessa J.I. Liontas (toim.), The TESOL Encyclopedia of English Language Teaching (ss. 1-6). Hoboken, NJ: Wiley Blackwell. https://doi.org/10.1002/9781118784235.eelt0106

DeKeyser, R. M. (2019). Age effects in second language learning, so obvious and so misunderstood. ELIA: Estudios de Lingüística Inglesa Aplicada, 19, 235-242.

Derwing, T. M. \& Munro, M. J. (2005). Second language testing and pronunciation teaching: A research-based approach. TESOL Quarterly, 39(3), 379-397. https://doi.org/10.2307/3588486

Derwing, T. M., \& Munro, M. J. (2009). Putting accent in its place: Rethinking obstacles to communication. Language Teaching, 42(4), 476-490. https://doi.org/10.1017/S026144480800551X

Derwing, T. M., \& Munro, M. J. (2015). Pronunciation fundamentals: Evidence-based perspectives for L2 teaching and research. Amsterdam: John Benjamins Publishing Company. https://doi.org/10.1075/11lt.42

Derwing, T. M., Munro, M. \& Wiebe, G. (1998). Evidence in Favor of a Broad Framework for Pronunciation Instruction. Language Learning, 48(3), 393-410. https://doi.org/10.1111/0023-8333.00047

Dörnyei, Z. (2009). The Psychology of Second Language Acquisition. Oxford: Oxford University Press.

Flege, J. E. (1995). Second language speech learning: Theory, findings, and problems. Teoksessa W. Strange (toim.), Speech perception and linguistic experience: Issues in cross-language research (ss. 233-277). Baltimore: York Press.

Foote, J. A., Trofimovich, P., Collins, L. \& Urzúa, F. S. (2016). Pronunciation teaching practices in communicative second language classes. The Language Learning Journal, 44(2), 181-196. https://doi.org/10.1080/09571736.2013.784345

Fraser, H. (2000). Coordinating improvements in pronunciation teaching for adult learners of English as a second language. Canberra: Commonwealth of Australia, Department of Education, Training and Youth Affairs. https://helenfraser.com.au/wp-content/uploads/ANTA-REPORT-FINAL.pdf

Good, A. J., Russo, F. A. \& Sullivan, J. (2015). The efficacy of singing in foreignlanguage learning. Psychology of Music, 43(5), 627-640. https://doi.org/10.1177/0305735614528833

Guilford, J. P. (1954). Psychometric methods. New York: MacGraw-Hill.

Hahn, L. D. (2004). Primary Stress and Intelligibility: Research to Motivate the Teaching of Suprasegmentals. TESOL Quarterly, 38(2), 201-223. https://doi.org/10.2307/3588378 


\section{Ainedidaktiikka 4(1) (2020)}

Hamp-Lyons L. (2007). The Impact of Testing Practices on Teaching. Teoksessa J. Cummins \& C. Davison (toim.), International Handbook of English Language Teaching (ss. 487-504). New York: Springer. https://doi.org/10.1007/978-0-387-46301-8 35

Hamzah, M. H. (2014, huhtikuu 9.-10.). The role of explicit phonetic instruction in pronunciation teaching in ESL settings. Esitelmä konferenssissa Prosiding seminar Antarabangsa Kelestarian Insan 2014. Johor, Indonesia. Haettu 13.3.2020 osoitteesta https://www.researchgate.net/profile/Mohd_Hilmi_Hamzah/publication/303336384 THE ROLE OF EXPLICIT PHONETIC INSTRUCTION IN PRONUNCIATION TEACHING IN ESL SETTINGS/links/573d80af08aea45ee84273ff/THE-ROLE-OF-EXPLICIT-PHONETIC-INSTRUCTION-IN-PRONUNCIATION-TEACHING-IN-ESL-SETTINGS.pdf

Hayes-Harb, R., Nicol, J. \& Barker, J. (2010). Learning the Phonological Form of New Words: Effects of Orthographic and Auditory Input. Language and Speech, 63(3), 267-381. https://doi.org/10.1177/0023830910371460

Heinonen, H. (tulossa). Uttalet i läroböcker i svenska från begriplighetsperspektiv. Puhe ja kieli.

Henderson, A., Curnick, L., Frost, D., Kautzsch, A., Kirkova-Naskova, A., Levey, D., Tergujeff, E. \& Waniek-Klimczak, E. (2015). The English Pronunciation Teaching in Europe Survey: Factors Inside and Outside the Classroom. Teoksessa J. Mompean \& J. Fouz-González (toim.), Investigating English Pronunciation: Trends and Directions (ss. 260-291). Basingstoke: Palgrave Macmillan. https://doi.org/10.1057/9781137509437 12

Hilden, R. (2020). Kielididaktiikka ja kieltenopettajan osaaminen muutosten edessä. Teoksessa R. Hilden, \& K. Hahl (toim.), Kielididaktiikan katse tulevaisuuteen haasteita, mahdollisuuksia ja uusia avauksia kielten opetukseen (ss. 5-29). Helsinki: Suomen ainedidaktinen tutkimusseura.

Huensch, A. (2019). Pronunciation in foreign language classrooms: Instructors' training, classroom practicies, and beliefs. Language Teaching Research, 23(6), 745-764. https://doi.org/10.1177/1362168818767182

Ilola, M. (2020). Oppilaiden käsityksiä englannin suullisesta kielitaidosta - suuntaviivoja suullisen kielitaidon opetukseen ja arviointiin. Teoksessa R. Hilden, \& K. Hahl (toim.), Kielididaktiikan katse tulevaisuuteen - haasteita, mahdollisuuksia ja uusia avauksia kielen opetukseen (ss. 129-151). Helsinki: Suomen ainedidaktinen tutkimusseura.

Ioup, G., Boustagui, E., El Tigi, M. \& Moselle, M. (1994). Reexamining the Critical Period Hypothesis: A Case Study of Successful Adult SLA in a Naturalistic Environment. Studies in Second Language Acquisition, 16(1), 73-98. https://doi.org/10.1017/S0272263100012596

IPA Chart, http://www.internationalphoneticassociation.org/content/ipa-chart, available under a Creative Commons Attribution-Sharealike 3.0 Unported License. Copyright (C) 2018 International Phonetic Association.

Jones, R. H. (1997). Beyond "listen and repeat": Pronunciation teaching materials and theories of second language acquisition. System, 25(1), 103-112. https://doi.org/10.1016/S0346-251X(96)00064-4

Kissling, E. M. (2013). Teaching pronunciation: Is explicit phonetics instruction beneficial for FL learners? The Modern Language Journal, 97(3), 720-744. https://doi.org/10.1111/j.1540-4781.2013.12029.x

Kissling, E. M. (2018). Pronunciation Instruction Can Improve L2 Learners' Bottom-Up Processing for Listening. The Modern Language Journal, 102(4), 653-675. https://doi.org/10.1111/modl.12512

Lamendella, J. T. (1977). General Principles of Neurofunctional Organization and Their Manifestation in Primary and Nonprimary Language Acquisition. Language Learning, 27(1), 155-196. https://doi.org/10.1111/j.1467-1770.1977.tb00298.x

Lawson, E., Stuart-Smith, J., Scobbie, M. \& Nakai, S. (2018). Seeing Speech: an articulatory web resource for the study of Phonetics. University of Glasgow. Haettu 9.1.2020 osoitteesta https://seeingspeech.ac.uk

Lee, J., Jang, J., \& Plonsky, L. (2015). The Effectiveness of Second Language Pronunciation Instruction: A Meta-Analysis. Applied Linguistics, 36(3), 345-366. https://doi.org/10.1093/applin/amu040 


\section{Ainedidaktiikka 4(1) (2020)}

Lehtonen, H. \& Räty, R. (2018). Kielitietoisia käytänteitä monikielisessä koulussa: kokemuksia toimintatutkimuksesta. Kieli, koulutus ja yhteiskunta, 9(3). Saatavilla: https://www.kieliverkosto.fi/fi/journals/kieli-koulutus-ja-yhteiskunta-toukokuu2018/kielitietoisia-kaytanteita-monikielisessa-koulussa-kokemuksia-toimintatutkimuksesta

Lenneberg, E. H. (1967). Biological foundations of language. New York: John Wiley \& Sons.

Lintunen, P. (2004). Pronunciation and Phonemic Transcription: A study of advanced Finnish learners of English. (Väitöskirja). Turun yliopisto.

Lintunen, P. (2014). Ääntämisen oppiminen ja opettaminen. Teoksessa P. Pietilä \& P. Lintunen (toim.), Kuinka kieltä opitaan (ss. 165-187). Helsinki: Gaudeamus.

Lintunen, P. \& Dufva, H. (2019). Suullinen kielitaito: mallit ja tavoitteet. Teoksessa E. Tergujeff \& M. Kautonen (toim.), Suullinen kielitaito - Opi, opeta, arvioi (ss. 42-58). Helsinki: Otava.

Lord, G. (2005). (How) Can We Teach Foreign Language Pronunciation? On the Effects of a Spanish Phonetics Course. Hispania, 88(3), 557-567. https://doi.org/10.2307/20063159

Ludke, K. M., Ferreira, F. \& Overy, K. (2014). Singing can facilitate foreign language learning. Memory \& Cognition, 42(1), 41-52. https://doi.org/10.3758/s13421-013-0342-5

Luukka, M.-R., Pöyhönen, S., Huhta, A., Taalas, P., Tarnanen, M. \& Keränen, A. (2008). Maailma muuttuu - mitä tekee koulu? Äidinkielen ja vieraiden kielten tekstikäytänteet koulussa ja vapaa-ajalla. Jyväskylä: Jyväskylän yliopisto, Soveltavan kielentutkimuksen keskus.

MacDonald, S. (2002). Pronunciation - views and practices of reluctant teachers. Prospect, 17(3), 3-18.

Marinova-Todd, S. H., Marshall, D. B., \& Snow, C. E. (2000). Three Misconceptions about Age and L2 Learning. TESOL Quarterly, 34(1), 9-34. https://doi.org/10.2307/3588095

Mompean, J. A. \& Lintunen, P. (2015). Phonetic notation in foreign language teaching and learning: potential advantages and learners' views. Research in Language, 13(3), 292-314. https://doi.org/10.1515/rela-2015-0026

Mora, C. F. (2000). Foreign language acquisition and the melody singing. ELT Journal, 54(2), 146-152. https://doi.org/10.1093/elt/54.2.146

Muñoz, C. \& Singleton, D. (2007). Foreign accent in advanced learners: Two successful profiles. EUROSLA Yearbook, 7(1), 171-190. https://doi.org/10.1075/eurosla.7.10mun

Murphy, J. M. (2017). Teacher training in the teaching of pronunciation. Teoksessa O. Kang, R. I. Thomson \& J. M. Murphy (toim.), The Routledge Handbook of Contemporary English Pronunciation (ss. 298-319). London: Routledge. https://doi.org/10.4324/9781315145006

Murphy, J., \& Baker, A. (2015). History of ESL pronunciation teaching. Teoksessa M. Reed \& J. M. Levis (toim.), The Handbook of English Pronunciation (ss. 3665). Chichester, UK: Wiley Blackwell.

Opetushallitus (2016). Perusopetuksen opetussuunnitelman perusteet 2014. Helsinki: Opetushallitus. Haettu 16.9.2019 osoitteesta https://www.oph.fi/sites/default/files/documents/perusopetuksen opetussuunnitelman perusteet 2014.pdf

Opetushallitus (2019). Varhaiskasvatussuunnitelman perusteet 2018. Helsinki: Opetushallitus. Haettu osoitteesta 16.9.2019 https://www.oph.fi/sites/default/files/documents/varhaiskasvatussuunnitelman perusteet.pdf

Opetus- ja kulttuuriministeriö (2018). Valtioneuvosto päätti peruskoulun tuntimäärän kasvattamisesta - kieltenopetus alkaa jatkossa jo ensimmäiseltä luokalta. Haettu 26.5.2019 osoitteesta https://minedu.fi/artikkeli/-/asset publisher/valtioneuvostopaatti-peruskoulun-tuntimaaran-kasvattamisesta-kieltenopetus-alkaa-jatkossa-joensimmaiselta-luokalta

Palo, P., Aalto, D., Aaltonen, O., Happonen, R-P., Malinen, J., Saunavaara, J. \& Vainio, M. (2012). Articulating Finnish Vowels: Results from MRI and Sound Data. Linguistica Uralica, 48(3), 194-199. https://doi.org/10.3176/lu.2012.3.05

Peltola, M., Lintunen, P., \& Tamminen, H. (2014). Advanced English learners benefit from explicit pronunciation teaching: an experiment with vowel duration and quality. AFinLA-E: Soveltavan kielitieteen tutkimuksia, 6, 86-98. Noudettu osoitteesta https://journal.fi/afinla/article/view/46282 


\section{Ainedidaktiikka 4(1) (2020)}

Pietilä, P. (2014). Yksilölliset erot kielenoppimisessa. Teoksessa P. Pietilä \& P. Lintunen (toim.), Kuinka kieltä opitaan (ss. 45-67). Helsinki: Gaudeamus.

Pietilä, P. \& Lintunen, P. (2014). Kielen oppiminen ja opettaminen. Teoksessa P. Pietilä \& P. Lintunen (toim.), Kuinka kieltä opitaan (ss. 11-25). Helsinki: Gaudeamus.

Pohjala, K. (2004). Suullinen kielitaito ja sen arviointi ylioppilastutkinnossa. Teoksessa R. Jaatinen, P. Kaikkonen \& J. Lehtovaara (toim.), Opettajuudesta ja kielikasvatuksesta - Puheenvuoroja sillanrakentajille (ss. 166-171). Tampere: Tampere University Press.

Pyykkö, R. (2017). Monikielisyys vahvuudeksi. Selvitys Suomen kielivarannon tilasta ja tasosta. Opetus- ja kulttuuriministeriön julkaisuja 2017:51. http://urn.fi/URN:ISBN:978-952-263-535-8

Rafat, Y. (2013). Orthography-induced transfer in the production of English-speaking learners of Spanish. Language Learning Journal, 44(2), 197-213. https://doi.org/10.1080/09571736.2013.784346

Rajab, H. (2013). Developing Speaking and Writing Skills of L1 Arabic EFL Learners through Teaching of IPA Phonetic Codes. Theory and Practice in Language Studies, 3(4), 653-659. https://doi.org/10.4304/tpls.3.4.653-659

Saito, K. (2011). Examining the role of explicit phonetic instruction in native-like and comprehensible pronunciation development: an instructed SLA approach to L2 phonology. Language awareness, 20(1), 45-59. https://doi.org/10.1080/09658416.2010.540326

Saito, K. (2012). Effects of Instruction on L2 Pronunciation Development: A Synthesis of 15 Quasi-Experimental Intervention Studies. Tesol Quarterly, 46(4), 842-854. https://doi.org/10.1002/tesq.67

Saito, K. (2013). Reexamining effects of form-focused instruction on L2 pronunciation development: The role of explicit phonetic information. Studies in Second Language Acquisition, 35(1), 1-29. https://doi.org/10.1017/S0272263112000666

Sakai, M. \& Moorman, C. (2018). Can perception training improve the production of second language phonemes? A meta-analytic review of 25 years of perception training research. Applied Psycholinguistics, 39(1), 187-224. https://doi.org/10.1017/S0142716417000418

Segalowitz, N., Freed, B., Collentine, J., Lafford, B., Lazar, N., \& Díaz-Campos, M. (2004). A Comparison of Spanish Second Language Acquisition in Two Different Learning Contexts: Study Abroad and the Domestic Classroom. Frontiers: The Interdisciplinary Journal of Study Abroad, 10, 1-18. Noudettu osoitteesta https://frontiersjournal.org/wp-content/uploads/2015/09/SEGALOWITZetalFrontiersX-AComparisonofSpanishSecondLanguageAcquisitioninTwoDifferentLearningContexts.pdf

Sopanen, P. (2018). Kielitietoisuus uudessa varhaiskasvatussuunnitelmassa. Kieli, koulutus ja yhteiskunta, 9(3). Saatavilla: https://www.kieliverkosto.fi/fi/journals/kielikoulutus-ja-yhteiskunta-toukokuu-2018/kielitietoisuus-uudessa-varhaiskasvatussuunnitelmassa

Sturm, J. L. (2013). Explicit phonetics instruction in L2 French: A global analysis of improvement. System, 41(3), 654-662. https://doi.org/10.1016/j.system.2013.07.015

Tella, S. \& Harjanne, P. (2004). Kielididaktiikan nykypainotuksia. Didacta Varia, 9(2), 25-52.

Tergujeff, E. (2010). Pronunciation teaching materials in Finnish EFL textbooks. Teoksessa A. Henderson (toim.), English Pronunciation: Issues and Practices (EPIP): Proceedings of the First International Conference. June 3-5 2009, Université de Savoie, Chambéry, France (ss. 189-205). Université de Savoie: Laboratoire LLS.

Tergujeff, E. (2012). The English Pronunciation Teaching in Europe Survey: Finland. Apples - Journal of Applied Language Studies, 6(1), 29-45. Noudettu osoitteesta http://apples.jyu.fi/article/abstract/222

Tergujeff, E. (2013). English Pronunciation Teaching in Finland. (Väitöskirja). Jyväskylän yliopisto. http://urn.fi/URN:ISBN:978-951-39-5322-5

Tergujeff, E. (2014). Lektio: Kolme väitettä englannin ääntämisen opetuksesta Suomessa. Puhe ja kieli, 34(1), 43-47. Noudettu osoitteesta https://journal.fi/pk/article/view/45206 


\section{Ainedidaktiikka 4(1) (2020)}

Tergujeff, E. (2019). Materiaalit suullisen kielitaidon opetuksessa. Teoksessa E. Tergujeff \& M. Kautonen (toim.), Suullinen kielitaito - Opi, opeta, arvioi (ss. 85-95). Helsinki: Otava.

Tergujeff, E., Heinonen, H., Ilola, M., Salo, O.-P. \& Kara, H. (2019). Suullisen kielitaidon opetus käytännössä. Teoksessa E. Tergujeff \& M. Kautonen (toim.), Suullinen kielitaito - Opi, opeta, arvioi (ss. 85-95). Helsinki: Otava.

Thomson, R. (2011). Computer Assisted Pronunciation Training: Targeting Second Language Vowel Perception Improves Pronunciation. CALICO Journal, 28(3), 744-765. https://doi.org/10.11139/cj.28.3.744-765

Thomson, R. I. \& Derwing, T. M. (2015). The Effectiveness of L2 Pronunciation Instruction: A Narrative Review. Applied Linguistics, 36(3), 326-344. https://doi.org/10.1093/applin/amu076

Ullakonoja, R. (2011). Da. Eto vopros!: prosodic development of Finnish students' read-aloud Russian during study in Russia. (Väitöskirja). Jyväskylän yliopisto. http://urn.fi/URN:ISBN:978-951-39-4209-0

Uchida, Y. \& Sugimoto, J. (2020). Non-native English teachers' confidence in their own pronunciation and attitudes towards teaching: A questionnaire survey in Japan. International Journal of Applied Linguistics, 30(1), 19-34. https://doi.org/10.1111/ijal.12253

Venkatagiri, H.S. \& Levis, J.M. (2007). Phonological awareness and speech comprehensibility: An exploratory study. Language Awareness, 16(4), 263-277. https://doi.org/10.2167/la417.0

Virkkunen, P. (2018). Kohti suullisia kielten yo-kokeita. Tempus, 1/2018, 18.

Wrember, M. (2001). Innovative approaches to the teaching of practical phonetics. Proceedings of the Phonetic Teaching and Learning Conference PTLC2001 (ss. 63-66). London: University College London.

Ylioppilastutkintolautakunta (2017). Toisen kotimaisen kielen ja vieraiden kielten digitaalisten kokeiden määräykset. Haettu 16.9.2019 osoitteesta https://www.ylioppilastutkinto.fi/images/sivuston_tiedostot/Ohjeet/Koekohtaiset/sahkoiset_kielikokeet maaraykset 30.11.2017 fi.pdf

Yousofi, N., \& Naderifarjad, Z. (2015). The Relationship between Motivation and Pronunciation: A case of Iranian EFL learners. Journal of Applied Linguistics and Language Research, 2(4), 249-262.

Yule, G., Hoffman, P. \& Damico, J. (1987). Paying Attention to Pronunciation: The Role of Self-Monitoring in Perception. TESOL Quarterly, 21(4), 765-768. https://doi.org/10.2307/3586994 